\title{
HOW CUSTOMER SUPPORT FOR CORPORATE SOCIAL RESPONSIBILITY INFLUENCES THE IMAGE OF COMPANIES: EVIDENCE FROM THE BANKING INDUSTRY
}

\begin{abstract}
The authors of this paper carry out two studies to determine whether customer support for Corporate Social Responsibility (CSR support) influences the way customers form their perceptions of CSR practices in the banking industry. Study 1 consists of a cluster analysis which provides information about four customer groups classified according to their support for CSR practices. These groups are labelled as the 'low support', 'social orientation', 'individual benefit' and 'high support' clusters. In Study 2, the authors test whether differences exists in the way the four clusters process their CSR perceptions. The results confirm the relevance of motivational attribution when socially oriented and highly involved customers evaluate CSR. Based on this information, the authors provide several recommendations for managers to effectively design and communicate their CSR strategies.
\end{abstract}

\section{KEYWORDS}

Corporate social responsibility, customer, CSR support, CSR image, cluster analysis, banking industry 


\section{INTRODUCTION}

There is a general perception that one of the main reasons corporate image is so intimately linked to Corporate Social Responsibility (CSR) nowadays is due to the change in the expectations people have about the role of businesses in society (Whitehouse, 2006). In this regard, the perspective of corporate marketing ( $\mathrm{He}$ and Balmer, 2007) highlights the need for businesses to broaden the scope of their activities and to focus on generating value beyond the maximization of profits. Companies should seek their survival through the commitment to the needs and expectations of stakeholders (Podnar and Golob, 2007; Melo and Garrido, 2012). Thus, CSR has become an important conditioning factor of public opinion and there has been a growing increase of CSR expectations among the media and other stakeholders (Dawkins and Lewis, 2003; Podnar and Golob, 2007). Furthermore, Pomering and Dolnicar (2009) believe that positive CSR perceptions also enhance customer attitudes towards companies especially when the person is highly supportive of CSR. However, the authors also point to a noticeable lack of interest in CSR on the part of customers. This fact clashes with information available about other stakeholders (Dawkins and Lewis, 2003).

In this paper, we question the idea that customers do not generally care about CSR (Pomering and Dolnicar, 2009) and propose that diverse types of customers can be identified based on their support for CSR. CSR support is defined as the interest of customers in CSR activities carried out by companies (Marín and Ruiz, 2007; Ramasamy et al, 2010). Along this line, Lii et al (2013) consider that "the level at which an event or object is mentally represented is contingent on the psychological distance from the event. Psychological distance reflects how far/close an event or object feels from the self in an abstract psychological space" (p.18). For the purpose of our research, that psychological distance that customers perceive between their self and corporate social initiatives explains the concept of customer CSR support.

We base our reasoning on a perception derived from an exploratory look at the international business context. There is evidence that nowadays CSR information has increased in the marketplace and that with the financial crisis social consciousness has arisen among customers. Marketplace polls report that customers not only expect 
businesses to be socially responsible, but they also want to be informed about what firms are doing. For example, in a survey conducted in America, 86\% of respondents said companies should tell them how they support CSR issues (Pomering and Dolnicar, 2009). In the UK, $74 \%$ of customers believe that additional information on a company's CSR commitment would influence their purchase behaviour while $86 \%$ think companies should actively communicate their CSR activities (Dawkins, 2004). Thus, it seems that the number of customers highly supportive of CSR is rising. Nevertheless, still different kinds of customers might exist depending on their support of CSR initiatives. We can see in this regard that $14 \%$ of customers in the UK do not give especial importance to CSR information while $26 \%$ would not modify their purchase decisions based on a detailed disclosure of CSR information (Dawkins, 2004). Nevertheless, academic research addressing CSR and customer perceptions and expectations is relatively rare to date (Podnar and Golob, 2007) and researchers in the field have called for further empirical studies to determine the level of actual customer support for CSR initiatives (Maignan, 2001; Mohr et al, 2001).

Furthermore, we also propose that customer CSR support affects how customers process their CSR perceptions and the way in which they form CSR images. In this regard, there is evidence that most studies analysing customer support for CSR are exploratory in nature (Cone Inc, 2004; Pomering and Dolnicar, 2009) and no papers exist which focus on empirically testing how customer CSR support affects customer cognitive structures and the ways in which these stakeholders process their CSR perceptions. Authors have analysed the role of CSR support in customer responses to CSR (Matute et al, 2011, Alniacik et al, 2011) but none of them advances the study of how customers get to CSR perceptions depending on their support for CSR activities. Also Pomering and Dolnicar (2009) highlight that previous research analysing the ability of CSR to produce positive consumer attitudes has mostly used an experimental approach where customer CSR support represents the independent variable that is experimentally manipulated. Nevertheless, the authors consider that it remains unclear whether real customers are supportive of CSR activities when facing real decisions. This lack of information leaves "a gap in our understanding of the CSR-consumer nexus" (Pomering and Dolnicar, 2009, p.286). 
Based on these ideas, the purpose of the authors in this paper is twofold. First, this paper is aimed at identifying a classification of customers according to their support for CSR activities in the banking industry. Secondly, we analyse how diverse levels of customer support for CSR initiatives influence the way customers process their CSR perceptions. Identifying these customer clusters and determining how they form CSR images will provide scholars and practitioners with a better understanding of the CSR-customer link. It will also allow us to segment the market for CSR and to propose interesting ways to better design and communicate CSR policies.

Our interest lies on the banking industry because, since the beginning of the financial crisis in 2007, society has devoted an increasing attention to CSR in this sector (Pérez et al, 2012). Banking institutions have experienced a significant transformation over time (Poolthong and Mandhachitara, 2009). Globalization, deregulation, de-intermediation, financial innovation and the development of new technologies that modify traditional distribution channels have caused the growing homogenization of institutions (Flavián et al, 2005). Homogenization increases competition and narrows the possibility for competitive advantages for any company in the sector. The international business climate during the last decade, characterised by frequent financial scandals and questionable accounting and managerial practices, only compounds the identity crisis of banking institutions (KPMG, 2008). All in all, the consequence of all these problems is the beginning of the global economic crisis in 2007, which led to the loss of society's confidence in banking institutions and increased the social conscience of stakeholders who now demand better tools for evaluating business practices (KPMG, 2008). As so, we can anticipate great expectations of customers regarding CSR in the banking industry and we believe that CSR support in this context surely plays a determining role in the formation of customer CSR perceptions.

For the purpose of our research, the paper starts by presenting a classic model to understand the formation process of CSR image among customers. Furthermore, the role of customer CSR support as a determinant of that process is analysed. The methodology implemented in the study is presented. In this regard, two different studies are developed: 1) In the first study a cluster analysis is carried out to determine whether it is possible to identify different groups of customers depending on their support for CSR; 2) secondly, the conceptual model proposed in the background section is tested in 
these clusters in order to determine whether differences exist regarding the formation process of CSR image among customers exhibiting diverse levels of CSR support. The main results of both studies are discussed. Finally, the most significant conclusions, limitations and future lines of research are presented.

\section{THE FORMATION OF CUSTOMER CSR PERCEPTIONS (CSR IMAGE)}

We base on the widely accepted model proposed by Rifon et al (2004) to understand customer mental processing of CSR perceptions. In this regard, we know that nowadays it is common for companies to associate their products and brands with other external objects they believe to be positively valued by customers (Bagui et al, 2009). The aim of this strategy is to provoke a positive image transfer from the external attribute to the company (Nan and Heo, 2007). In sponsorship, for example, the brand is associated with a prestigious event; a celebrity endorsement matches the product with a known public figure; the brand extension strategy links a new product with an existing reputable brand; and in cause-related marketing $(\mathrm{CrM})$ the product is associated with a non-profit organisation or a social cause for which stakeholders have a positive attitude (Varadarajan and Menon, 1988; Rifon et al, 2004; Bagui et al, 2009).

Nevertheless, literature has suggested that the transfer does not occur equally in all situations and that diverse circumstances mediate the formation of CSR perceptions (Hoeffler and Keller, 2002; van Herpen et al, 2003; Rifon et al, 2004; Becker-Olsen et al, 2006, Ellen et al, 2006). Rifon et al (2004) propose a causal model that explains the effect of company-CSR congruence, the attribution of corporate motivations to engage in CSR and corporate credibility on customer attitudes towards the CSR of the organization. The results of this study confirm the value of an enterprise's involvement in sponsoring CSR projects which are perceived by customers as: 1) consistent with core business activities and products (company-CSR congruence), 2) altruistic in nature (motivational attribution) and 3) credible (corporate credibility). First, congruence generates stronger customer attributions of altruistic corporate motivations, credibility and customer attitude towards then company than incongruence. Secondly, customer perceptions of corporate altruistic motivations mediate the relationship between congruence and credibility. Finally, credibility perceptions mediate the relationship between corporate motive assessment and customer attitude. Table 1 summarises 
previous papers which have positively confirmed the adequacy of Rifon's et al (2004) model to diverse research contexts.

\section{Insert Table 1. here}

Thus, before we test the role of customer CSR support on the formation of CSR perceptions we propose six research hypotheses to confirm the validity of Rifon's et al (2004) model in the context of our research:

H1: Company-CSR congruence directly and positively influences motivational attributions.

H2: Company-CSR congruence directly and positively influences corporate credibility.

H3: Motivational attributions directly and positively influence corporate credibility.

H4: Corporate credibility directly and positively influences CSR image.

H5: Company-CSR congruence directly and positively influences CSR image.

H6: Motivational attributions directly and positively influence CSR image.

\section{THE ROLE OF CUSTOMER CSR SUPPORT}

Although the model of Rifon et al (2004) has been extensively tested, even these authors argue that feasible moderating effects on the formation process of customer CSR perceptions have been ignored. Based on both theoretical and empirical evidence, in this paper we propose that customer CSR support might be one of those variables largely overlooked in academic literature. Because social consciousness is rising and few customer information is available, determining whether different customer types can be identified depending on their CSR support will provide new relevant information to CSR literature while it will also offer significant opportunities for practitioners to know how to segment the market in order to implement ad-hoc CSR strategies. In this regard, customer psychological features, such as CSR support, have long been used as interesting variables for market segmentation (Roberts, 1996). 
First, it is interesting that researchers have demonstrated that customers tend to incorporate their expectations and concerns into their behaviour towards companies (Maignan et al, 2005; Podnar and Golob, 2007). In the case of CSR, authors demonstrate that the extent to which customers will reward (or punish) the CSR behaviour of a company is a function of their CSR support and expectations (Creyer and Ross, 1997). Many customers are willing to put pressure on companies to behave more responsibly in such forms as customer boycotts, ethical buying or ethical purchasing behaviour. Thus, CSR support serves as a reference point for customer intentions to behave in a proactive and positive or negative manner towards companies (Creyer and Ross, 1997; Podnar and Golob, 2007). Thus, if customer CSR support influences customer behaviour when faced with CSR information, it also makes sense to believe that CSR support might determine the way customers process their CSR perceptions. Nevertheless, this proposition has been scarcely studied so far and new empirical evidence is needed in this regard (Maignan, 2001; Mohr et al, 2001).

One of the few attempts to relate CSR support and CSR image is the paper by Mohr and Webb (2005) who corroborate the greater effect of CSR activities on corporate image and purchase intentions when customers highly support CSR. Marín and Ruiz (2007) analyse CSR support as a precursor of corporate identity attractiveness. The authors state that the greater the customer support for CSR the greater their identification with the company. In the end, this leads to greater identity attractiveness and a better valuation of the company. Similarly, legitimacy theory (Handelman and Arnold, 1999) also manifests the relationship between a customer's altruistic character and their perception of corporate identity. It is specifically proposed that people with an altruistic nature are more socially sensitive and are more inclined to support CSR initiatives. In this case, the helping nature of the person will lead to a better valuation of CSR mediated by customer CSR support.

In this paper, we consider that the greater the customer support for CSR, the more thoughtful the formation process of CSR image will be. In a CSR communication context, Bigné et al (2009) consider that CSR support influences the amount of elaboration existing in the processing of information when the customer evaluates corporate image. Thus, CSR support leads to a greater customer CSR involvement because customers higly supportive of CSR are willing to make extra efforts to 
rationally evaluate CSR practices. In this regard, the dual-process model (Petty and Cacioppo, 1986) proposes that, with the increasing involvement of an individual in the communicated message, persuasion is produced through a central route, as the individual perceives it necessary to form a reasoned opinion about the issue to be able to more deeply and formally evaluate its true nature. In contrast, when CSR involvement is low, the individual evaluates the main content of the message with heuristics, which are less diagnostic but more accessible, producing persuasion through a peripheral route. This approach has been tested positively in the context of CSR sponsorship and causerelated marketing (CrM) (Speed and Thompson, 2000).

In addition, in the context of $\mathrm{CrM}$ and the sponsorship of social causes it has been confirmed that perceptions of company-CSR congruence, motivational attribution and corporate credibility gain in diagnostic ability and accessibility, tending to be used by supportive customers more frequently (Bigné et al, 2009). For example, Bigné et al (2009) consider that altruistic consumers perceive CSR messages as a threat to their own self-identity so they tend to be more critical towards the brand in an attempt to protect their self-esteem and personal identity. This defence allows them to ensure that they are not being manipulated or deceived. Altruism raises suspicion and lead customers to be stricter in their assessment of the brand which is based on facts and information that legitimate the veracity of the brand's socially responsible intentions (Menon and Kahn, 2003). On the contrary, non-altruistic customers are likely to not perceive CSR campaigns as a special threat to their self-concept (Bigné et al, 2009) so they do not need to legitimate CSR initiatives and they do not evaluate so many heuristics when forming a CSR image of businesses. They trust in more accessible indicators and information regarding other behaviours of companies will have a halo effect when judging CSR.

All in all, CSR support makes of company-CSR congruence, motivational attribution and credibility more effective determinants of CSR image, strengthening their positive (or negative) effects on CSR image. Based on these ideas, we propose a new research hypothesis: 
H7: The degree to which a customer supports CSR moderates the formation process of CSR image. The greater the customer CSR support the stronger the relationship between...

H7a: ...company-CSR congruence and motivational attribution.

H7b: ...company-CSR congruence and corporate credibility.

H7c: ...motivational attribution and corporate credibility.

H7d: ...corporate credibility and CSR image.

H7e: ...company-CSR congruence and CSR image.

H7f: ...motivational attribution and CSR image.

Figure 1 shows the conceptual model we test in this paper:

\section{Insert Figure 1 here.}

\section{METHODOLOGY}

The research is divided in two studies. In the first one, a cluster analysis is performed to determine if it is possible to identify diverse customer groups depending on their support for CSR. In the second one, the research hypotheses are tested.

\section{Study 1 -Cluster analysis}

\section{Sample}

For both studies a research based on personal surveys to customers of banking services in a Southern European country was conducted. To design the research sample, a nonprobabilistic sampling procedure was used. With the purpose of guaranteeing a more accurate representation of the data, a multi-stage sampling by quotas was used based on customer gender and age. The field work was performed in April 2010, and after the collection and processing of the information, a total of 1,124 valid surveys remained (response rate $=93.67 \%$ ). The sample was $48.52 \%$ male and $51.48 \%$ female, which was comparable to the representative population of the country (Instituto Nacional de Estadística, data up to January 1, 2009) with $49.03 \%$ female and $50.97 \%$ male. Regarding age, customers in the sample were $46.62 \%$ under 44 (50.14\% in the national 
population), $31.70 \%$ between 45 and 64 (29.68\% in the national population) and $21.69 \%$ over 64 (20.19\% in the national population).

\section{Measurement scale}

To measure CSR support we used the scale previously proposed by Pérez et al (2012) to evaluate customer CSR perceptions. In this regard, we used this proposal because few studies had attempted to measure CSR support before (Sen and Bhattacharya, 2001; Mohr and Webb, 2005; Marín and Ruiz, 2007; Podnar and Golob, 2007). Furthermore, there are significant limitations in these papers because they only gather dispersed dimensions of CSR (minorities, the environment or philanthropy, among others). Thus, these scales do not gather all of the CSR initiatives developed in the banking industry (Pérez et al, 2012). For example, Maignan (2001) criticises these studies for drawing conclusions on too narrow a conceptualisation of CSR and focusing only on one or two CSR activities which do not represent the full spectrum of CSR initiatives. CSR can be understood as a balance of all responsibilities and policies which meet or exceed expectations, values and norms of stakeholders and society at large (Sen and Bhattacharya, 2001). Thus, previous papers offer very limited insights into customer expectations of CSR (Pomering and Dolnicar, 2009). Pérez et al (2012) consider that the CSR debate implies corporate behaviour which embeds a variety of social obligations towards stakeholders, namely, customers, shareholders and supervising boards, employees and society. They also include a general dimension compounded of legal and ethical responsibilities. The measure is compounded of 22 items which evaluate responsibilities in these five dimensions by means of 7-point Likert-type sentences (Table 3). The authors base their scale on previous proposals by Maignan et al (1999), Maignan (2001), Mercer (2003), Decker (2004) and García de los Salmones et al (2005). Responsibilities towards customers basically refer to complete and honest communication of corporate products and services and the management of complaints. Corporate responsibilities towards shareholders and supervising boards are especially oriented to the evaluation of corporate profitability and information transparency. Responsibilities towards employees are related to job creation and employment opportunities such as career development, equal opportunities, training, conciliation and the offer of social benefits. Society concerns refer to charity, community development and environmental protection. Finally, the general dimension of CSR support is 
compounded by ethical and legal concerns which refer to general corporate responsibilities that do not benefit specific stakeholders but all of them to the same extent.

\section{Identification and characteristics of cluster groups}

Cluster analysis was performed based on the five extracted dimensions of CSR support to determine the optimal heterogeneous groups in our research (Chiang et al, 2011). A $\mathrm{K}$-means clustering method was employed to produce the proper number of groups for adequate market segmentation (Hair et al, 2010). Furthermore, an ANOVA analysis was run to examine whether statistically significant differences existed among these clusters based on the importance ratings of the CSR dimensions. As a result, four groups of customers were identified and found to have different demographic profiles (Table 2).

\section{Insert Table 2 here.}

Table 2 indicates that the largest cluster comprises those customers showing "high support" for CSR activities (46.4\%). This cluster is found to be the most supported for CSR, as customers place the greatest importance on all those social initiatives that favour each stakeholder. Especially significant is the responsibility of the institutions to uphold the legal and ethical guidelines applicable to their activity sector (Mean=6.746) while those topics which are relevant to employees (Mean=6.644) and customers (Mean=6.630) are also significant. Worth noting is the lower interest that philanthropy (society) (Mean=6.439) and the economic benefits for shareholders (Mean=6.276) awaken in these customers. The population in this group is mainly composed of employed customers (57.2\%), women (58\%), over $45(56.8 \%)$, with a high school $(42.2 \%)$ or college degree (34\%). A significant number of retired customers $(21.1 \%)$ is also observed in this group. At the same time, the smallest group is labelled the "low support" cluster (9.5\%). The profile of this cluster is dominated by educated $(46.7 \%$ with a college degree and $36.4 \%$ with a high school degree), employed (59.7\%) and young $(53.3 \%$ under 44$)$ men $(57.9 \%)$.

So far, the results confirm previous findings in academic literature, where scholars have analysed the effects of CSR support based on the identification of these two -low and 
high support- clusters (Sen and Bhattacharya, 2001). Nevertheless, the first significant contribution of this paper is the identification of two more groups of customers who exhibit a significant different perception when it comes to evaluating CSR. Thus, a third group is compounded of customers oriented to their own "individual benefit" when they evaluate CSR initiatives (24.6\%). This group is characterised by the special interest customers show in anything related to the benefit of the customer (Mean=6.160) and/or shareholder (Mean=5.890), at the expense of society (Mean=4.885). They consider benefits to society to be of little relevance for banking institution. These banking service users are, again, predominantly male (56.3\%), employed (55.9\%) and college educated (39.4\%). Finally, the last group is the "social orientation" cluster (19.5\%). These customers place a special importance on the legal and ethical dimension of business activity (Mean=5.774). The 'customers' (Mean=5.562) and 'society' (Mean=5.500) dimensions are also significantly relevant in this cluster, followed by the responsibilities towards employees (Mean=5.212) and shareholders (Mean=4.710). Regarding the composition of the population in this cluster, significant characteristic are also observed: this group consists of older people (55.4\% over 45$)$, with a slightly lower educational level $(26.9 \%$ does not have any education or they have only completed elementary school). Furthermore, a considerable volume of customers are retired $(23.3 \%)$.

\section{Study 2 - Hypotheses testing}

The second study in this paper was oriented to test the research hypotheses already presented in the background section. First, hypotheses H1 to H6 were tested in the global sample. Since these hypotheses did not consider possible differences among customer clusters, the purpose of the researchers was to determine whether the proposed model of the formation process of CSR image fitted well to the behaviour of regular customers, independently of their CSR support (Bigné et al, 2009). Secondly, a multisampling analysis was conducted to test the moderator role of CSR support (hypothesis $\mathrm{H} 7-7 \mathrm{a}$ to $7 \mathrm{f}-$ ). Before the results of both analyses are presented, the measurement tools used in both cases are defined. 
Variables were measured with multi-item 7-point Likert-type scales (Table 3). First, CSR image was measured with the scale proposed by Pérez et al (2012) which we already used to evaluate CSR support. This procedure is especially interesting since it facilitates the identification of significant conclusions when comparing CSR support and corporate image. The methodology has already been successfully implemented by David et al (2005) in their study on the relationship between CSR perception and customer purchase behaviour. Nevertheless, we acknowledge that measuring both CSR support and CSR image at the same point in time and from the same source of information (customers) might be a significant source of method bias in our study (Podsakoff et al, 2003). We applied Podsakoff's et al (2003) recommendations to reduce biases to a minimum. Specifically, we included the CSR support and CSR image scales as part of a larger questionnaire which allowed us to separate the dimensions in the scales both temporally and psychologically (Podsakoff et al, 2003). A 4-item scale based on previous proposals by Lafferty et al (2004) and Bigné et al (2009) was developed to measure corporate-CSR congruence, which refers to the symbolic similarity between corporate personality and the CSR policy. Motivational attribution was measured by means of a 4-item scale oriented to identify customer perceptions of the altruistic nature of the company in developing its CSR initiatives. In designing the scale, the works of Becker-Olsen et al (2006) and Bigné et al (2009) were taken as references. Finally, to measure corporate credibility Newell and Goldsmith's (2001) proposal was adopted. A 4-item scale was used where two items measured corporate CSR expertise and two items measured corporate trustworthiness.

\section{Insert Table 3 here.}

\section{Results for hypotheses H1 to H6}

First, the goodness of Rifon's et al (2004) model was globally tested to ensure that it fitted properly to the data independently of the differences among customers. As a first step, the validation of the measurement scales was performed to confirm the goodness of fit of the model, as well as the convergent and discriminant validity between the different concepts that composed this model. The Comparative Fit Indexes in all cases 
exceeded the minimum recommended value of 0.90 (NFI=0.926; NNFI=0.927; $\mathrm{CFI}=0.939$; $\mathrm{IFI}=0.940$ ), and the Satorra-Bentler $\chi^{2}$ was also non-significant (S$\mathrm{B} \chi 2=820.14$, $\mathrm{p}$-value $>0.05)$, demonstrating a good fit of the model. In addition, the standardised lambdas obtained for the latent concepts were significant and greater than 0.50 , ensuring the convergent validity of the model. Finally, the discriminant validity of the factorial structure was evaluated by estimating the confidence intervals for the correlation between pairs of variables. The results also verified the discriminant validity of the model.

Once the validity of the measurement scales was successfully tested, the estimation of the causal relationships was performed with the statistical software EQS 6.1. The results of the analysis are shown in Table 4. The results confirm the proposed relations between the first three model concepts: company-CSR congruence, motivational attribution and corporate credibility. First, company-CSR congruence directly influences motivational attribution $(\beta=0.266 ; p<0.05)$ and corporate credibility $(\beta=0.266 ; p<0.05)$. Secondly, motivational attribution also positively influences customer perceptions of corporate credibility $(\beta=0.459 ; \mathrm{p}<0.05)$. Based on these results, hypotheses $\mathrm{H} 1$ to $\mathrm{H} 3$ cannot be rejected. Results also show the value of getting companies to inspire credibility in developing their CSR programs because this allows them to further improve their CSR image $(\beta=0.290 ; p<0.05)$. Consequently, hypothesis $\mathrm{H} 4$ is not rejected. Finally, the results show that company-CSR congruence directly contributes to the generation of corporate image $(\beta=0.213 ; \mathrm{p}<0.05)$ so it is not possible to reject the hypothesis H5. Furthermore, the attribution of altruistic or egoistic motivations automatically determines the CSR image of a banking institution $(\beta=0.235 ; \mathrm{p}<0.05)$, such that hypothesis H6 should also not be rejected.

\section{Insert Table 4 here.}

\section{Results for hypotheses H7a to H7f}

To test the moderating role of CSR support in the formation process of CSR image the four customer clusters identified in study 1 were taken into consideration. The structural equation model was first tested in each of the clusters to obtain a multi-group solution of causal relationships where it was of special interest for the researchers to know the 
value of the standardised coefficients of the proposed relationships. A second step of the multisampling analysis consisted of the test of the factorial invariance of the proposed model among the identified clusters, an essential requirement to ensure that the constructs were understood in the same way among different customers and thus the model was comparable. The factorial invariance was studied through the Lagrange Multiplier (LM) test, which allowed the researchers comparing chi-square differences of the relationships when the restriction concerning the equality among the factorial lambdas in the diverse clusters was eliminated. When the results of this analysis showed non-significant values in the improvement of the chi-square $(p>0.05)$, the factorial invariance was confirmed. Finally, the proposed structural equation model was estimated including the restriction that the betas of the relationships between all constructs were equal among groups (structural invariance). Again, the suitability of this restriction was tested with the LM test. This time, it was necessary that the chi-square differences were significant $(\mathrm{p}<0.01$ for a $99 \%$ confidence, $\mathrm{p}<0.05$ for a $95 \%$ confidence, $\mathrm{p}<0.1$ for a $90 \%$ confidence) to confirm that CSR support was a moderator of the relationship under scrutiny.

\section{Insert Table 5 here.}

Regarding the results of these analyses (Table 5), first it is observed that the essential proposition of the authors is confirmed: the greater the support of customers for CSR, the more number of variables these subjects take into consideration when forming a CSR image of their banking providers. For example, while the model does not fit particularly well to the cluster exhibiting the lowest support for CSR (S-B $2^{2}$ $(112)=147.83(\mathrm{p}=0.01) ; \mathrm{NFI}=0.715 ; \mathrm{NNFI}=0.886 ; \mathrm{CFI}=0.906 ; \mathrm{IFI}=0.912)$, it gains in diagnosticity when customers care more about social responsibilities of corporations (S$\mathrm{B} \chi 2(112)=280.03(\mathrm{p}=0.00) ; \mathrm{NFI}=0.922 ; \mathrm{NNFI}=0.941 ; \mathrm{CFI}=0.952 ; \mathrm{IFI}=0.952)$. Thus, only one relationship is confirmed among lowly involved customers while four, five and all the relationships are positively tested in the 'social orientation', 'individual benefit', and 'high support' clusters respectively. Among lowly involved customers, only company-CSR congruence positively influences corporate credibility $(\beta=0.48$, $\mathrm{p}<0.05)$. Among customers exhibiting a social orientation, company-CSR congruence positively influences motivational attribution $(\beta=0.26, \mathrm{p}<0.05)$ and credibility $(\beta=0.38$, $\mathrm{p}<0.05)$; motivational attribution determines corporate credibility $(\beta=0.44, p<0.05)$; and 
corporate credibility directly affects CSR image $(\beta=0.38, \mathrm{p}<0.05)$. Among customers exhibiting an individual orientation, company-CSR congruence positively influences motivational attribution $(\beta=0.30, p<0.05)$ and credibility $(\beta=0.29, p<0.05)$; motivational attribution determines corporate credibility $(\beta=0.55, p<0.05)$ and CSR image $(\beta=0.23$, $\mathrm{p}<0.05)$; and corporate credibility directly affects $\operatorname{CSR}$ image $(\beta=0.26, \mathrm{p}<0.05)$. Finally, all the relationships in the causal model are accepted. Company-CSR congruence positively influences motivational attribution $(\beta=0.21, \mathrm{p}<0.05)$, credibility $(\beta=0.38$, $\mathrm{p}<0.05)$ and CSR image $(\beta=0.20, \mathrm{p}<0.05)$; motivational attribution determines corporate credibility $(\beta=0.53, \mathrm{p}<0.05)$ and CSR image $(\beta=0.32, \mathrm{p}<0.05)$; and corporate credibility directly affects CSR image $(\beta=0.26, p<0.05)$.

It is also observed that the connection between company-CSR congruence and corporate credibility is significantly stronger (Dif $X^{2}(1)$; $\left.<<0.05\right)$ for the 'low support' cluster $(\beta=0.48 ; \mathrm{p}<0.05)$ than for the 'social orientation' $(\beta=0.38 ; \mathrm{p}<0.05)$, the 'individual benefit' $(\beta=0.29 ; \mathrm{p}<0.05)$ and the 'high support' $(\beta=0.38 ; \mathrm{p}<0.05)$ clusters. These results are contrary to the initial proposition of the authors so hypothesis $\mathrm{H} 7 \mathrm{~b}$ must be rejected. Nevertheless, the results are consistent with previous findings in literature such as the ones of Bigné et al (2009). As a justification for these findings, the authors consider that, since CSR campaigns do not represent a threat to the self-concept of non-altruistic customers, these subjects will not find essential to base their brand judgement on the attribution of altruistic motivations, but it will be enough to trust on a more accessible indicator such as cause-brand fit to value brand credibility in its attempt to persuade through CSR. Roughly speaking, these customers will accept mixed motivations on the part of companies.

On the contrary, hypotheses H7e and H7f cannot be rejected based on our results. We can see in Table 5 that the positive relationship theoretically proposed between company-CSR congruence and CSR image (H7e) and motivational attribution and CSR image (H7f) is only positively tested among customers highly supportive of CSR. For example, company-CSR congruence does not have a direct impact on CSR image neither in the 'low support' $(\beta=0.14, \mathrm{p}>0.05)$, nor in the 'social orientation' $(\beta=0.01$, $\mathrm{p}>0.05)$ or the 'individual benefit' $(\beta=0.10, \mathrm{p}>0.05)$ clusters. However, company-CSR congruence becomes a key determinant of CSR image among highly supportive customers $(\beta=0.20, \mathrm{p}<0.05)$. Thus, hypothesis $\mathrm{H} 7 \mathrm{e}$ is accepted. A similar situation is 
observed for the relationship between motivational attribution and CSR image (H7f). This time, we can see that the relationship is not statistically significant in the 'low support' $(\beta=0.113, p>0.05)$ and 'social orientation' $(\beta=0.04, p>0.05)$ clusters, while it is positive and significant among individualists $(\beta=0.23, \mathrm{p}<0.05)$ and supportive customers $(\beta=0.32, \mathrm{p}<0.05)$, who are customers more interested in CSR than the other two clusters. According to this result, hypothesis $\mathrm{H} 7 \mathrm{f}$ is also accepted.

Finally, hypotheses H7a, H7c and H7d must be only partially accepted according to the findings in this paper. Actually, the fact that some of the relationships proposed among constructs are positively tested in some clusters but not in others supports the acceptance of the hypotheses. For example, when the relationship between companyCSR congruence and motivational attribution ( $\mathrm{H} 7 \mathrm{a})$ is not supported in the 'low support' cluster $(\beta=0.14 \mathrm{p}>0.05)$ although it is positively tested in the 'social orientation' $(\beta=0.26 ; p<0.05)$, 'individual benefit' $(\beta=0.30 ; p<0.05)$ and 'high support' $(\beta=0.21 ; p<0.05)$ clusters, it is demonstrated that this connection is stronger among more supportive customers. Nevertheless, all these three hypotheses can only be partially accepted because, when the relationships are positively tested in diverse clusters, significant differences are not observed among them ( $p>0.05)$. For example, regarding hypothesis $\mathrm{H} 7 \mathrm{a}$, differences in the betas of the relationship are statistically non-significant between customers socially oriented and customers driven by their individual benefit (Dif X2(1) II-III $=0.01 ; \mathrm{p}>0.05$ ). They are not significant between customers socially oriented and highly supportive customers either (Dif X2(1) II-IV = $0.04 ; \mathrm{p}>0.05)$. Finally, they are not significant between individually-driven and supportive customers (Dif X2(1) III-IV $=0.028 ; \mathrm{p}>0.05$ ).

\section{CONCLUSIONS}

First, this research has highlighted the possibility of segmenting the market as a function of customer support for CSR. Four clusters have been identified with different psychological and demographic traits such as CSR support, gender, age, educational level and occupation. The identification of these clusters extends previous research in academic literature which have generally considered just two opposite groups when defining the socially conscious customer -low and high CSR support- (e.g. Roberts, 1996; Sen and Bhattacharya, 2001). 
It is also interesting to confirm that customers who are not supportive of CSR represent a relatively small portion of the banking market. Just $9.5 \%$ of customers were classified in this category. On the contrary, the largest amount of customers where classified as people highly interested in CSR. $46.4 \%$ of customers in this sector are highly supportive of CSR initiatives. These results confirm our first intuition: it is untrue that customers do not generally care about CSR. By concluding this, we contradict previous results by authors such as Pomering and Dolnicar (2009), and we demonstrate that CSR is a concept constantly evolving and which has become a key of public opinion regarding banking institutions worldwide. Companies not developing a CSR strategy in the current competitive scenario will surely face serious difficulties to recover from the financial crisis and will quite surely undermine their own corporate images and reputation.

Companies should also bear in mind that customers are motivated by different CSR dimensions when evaluating corporate strategies. In this regard, we have identified two additional clusters with significantly different interests in CSR. First, customers socially oriented represent $19.5 \%$ of the banking industry nowadays. These customers care about the legal and ethical dimension of CSR just as no other customer does. Customers individually driven care about customer's and shareholder's issues while they overlook social issues. This cluster represents $24.6 \%$ of the banking market. Thus, we understand that CSR must necessarily be a multidimensional concept in the corporate strategy of banks which should never underestimate any of its dimensions if they want to effectively manage CSR perceptions among their customers.

In this regard, the findings in this paper allow practitioners to design and establish personalised relationships with every kind of customer thus improving the efficiency and positive outcomes of CSR strategies. In line with the propositions of the relationship marketing perspective, this fact would contribute to improving customer satisfaction and loyalty. For example, it seems that women and customers over 64 might be more socially-concerned than men and young customers who seem to be more individualistic when evaluating CSR. This second cohort is classified either in the 'low support' or 'individual benefit' cluster. Thus, it might be interesting for companies to especially orient their CSR strategies and communications to the CSR concerns of both 
women and elder customers because they will take into consideration their CSR perceptions when globally evaluating the company and taking purchase decisions. When approaching younger male customers companies should better not devote great efforts to highlight their social commitments since these customers are lowly supportive of CSR and they tend to pay greater attention to commercial and economic issues.

Based on our results, it also seems interesting that banking institutions specially concentrate on highlighting their commitment to ethical and legal standards as well as to the fulfilment of customer related concerns. On the other hand, responsibilities towards society at large or shareholders are not that positively assessed by most customers and enhancing their visibility would result in poorer CSR perceptions.

Furthermore, when it comes to understanding the formation process of CSR image, results are also influenced by customer support for CSR initiatives. Thus, the role of company-CSR congruence, motivational attribution and corporate credibility must be clarified based on the market segmentation proposed in this paper. It has been observed that Rifon's et al (2004) model is especially accurate when it comes to understanding the way customers who are socially oriented think of corporate image and how they process information to evaluate CSR. Nevertheless, customers who are lowly supportive of CSR elaborate a less thoughtful perception of CSR practices since they do not consider as many heuristics as highly supportive customers. Also, highly supportive customers especially base their CSR perceptions on motivational attribution while the low support cluster gives more importance to company-CSR congruence. Based on these ideas, it seems necessary that companies promoting their CSR initiatives especially concentrate on demonstrating the absence of self-interested motivations because that is the main precursor of positive perceptions among those customers who are receptive to CSR information. In the end, the attribution of altruistic reasons for the company to invest in CSR will lead conscious customers to improve their corporate perceptions and will strengthen the customer-company nexus. These results imply that unconditional CSR investments (e.g., unconditional donations or the sponsorship of social causes) where the company is not perceived to get an immediate economic compensation would derive in better customer perceptions than conditioned investments (e.g., $\mathrm{CrM}$ ) where the donation is not made by the company but the organization acts as a mere agent connecting the social cause with customers. 
Finally, some limitations of the study are identified and future lines of research are discussed. First, it is well-known that the unverifiable nature of many CSR claims, such information obtained directly from companies, is likely to be treated with a greater degree of scepticism than more provable search and experience claims. This reality might have influenced the results in our paper and new research should be devoted to control the influence of different information sources (e.g., corporate communication, the media, etc). Also, in this paper we have proved a valid model to understand the way customers highly supportive of CSR process their CSR perceptions. However, the model proved to be inefficient to understand lowly supportive customers. The authors consider that it would be interesting to identify a better way to anticipate CSR image in the low support cluster, which could include more accessible information and the halo effect of business practices.

\section{REFERENCES}

Alniacik U, Alniacik E, Genc N. 2011. How corporate social responsibility information influences stakeholders' intentions. Corporate Social Responsibility and Environmental Management 18(4): 234-245.

Becker-Olsen KL, Cudmore BA, Hill RP. 2006. The impact of perceived corporate social responsibility on consumer behavior. Journal of Business Research 59(1): 46-53.

Bigné E, Currás R, Sánchez I. 2009. Brand credibility in cause-related marketing: The moderating role of consumer values. The Journal of Product and Brand Management 18(6): 437-447.

Chiang M, Fan Y, Chiang CWM, Wang ETG. 2011. Clustering Chinese visitors based on Chinese cultural values. The Business Review 19(1): 118-126.

Cone Inc. 2004. Cone corporate citizenship study. Available online: http://www.coneinc.com.

Creyer EH, Ross WT. 1997. The influence of firm behaviour on purchase intention: Do consumers really care about business ethics? Journal of Consumer Marketing 14(6): 421-432.

David P, Kline S, Dai Y. 2005. Corporate social responsibility practices, corporate identity, and purchase intention: A dual-process model. Journal of Public Relations Research 17(3): 291-313. 
Dawkins J. 2004. The public's views of corporate responsibility 2003. White Paper Series, MORI. Available online: http://mori.com.

Dawkins J, Lewis S. 2003. CSR in stakeholder expectations: And their implication for company strategy. Journal of Business Ethics 44(2/3): 185-193.

Decker OS. 2004. Corporate social responsibility and structural change in financial services. Managerial Auditing Journal 19(6): 712-728.

Ellen PS, Webb DJ, Mohr LA. 2006. Building corporate associations: Consumer attributions for corporate socially responsible programs. Journal of the Academy of Marketing Science 34(2): 147-157.

Flavián C, Guinalíu M, Torres E. 2005. The influence of corporate image on consumer trust: A comparative analysis in traditional versus internet banking. Internet Research 15(4): 447-470.

García de los Salmones MM, Herrero A, Rodríguez del Bosque I. 2005. Influence of corporate social responsibility on loyalty and valuation of services. Journal of Business Ethics 61: 369-385.

Hair JF, Black WC, Babin BJ, Anderson RE. 2010. Multivariate data analysis, 7th edition. Prentice-Hall: Upper Saddle River, NJ.

Handelman JM, Arnold SJ. 1999. The role of marketing actions with a social dimension: Appeals to the institutional environment. Journal of Marketing 63(3): 33-48. He H, Balmer JMT. 2007. Identity studies: Multiple perspectives and implications for corporate-level marketing. European Journal of Marketing 41(7/8): 765-785.

Hoeffler S, Keller KL. 2002. Building brand equity through corporate societal marketing. Journal of Public Policy \& Marketing 21(1): 78-89.

KPMG. 2008. KPMG international survey of corporate responsibility reporting 2008.

Lafferty BA, Goldsmith RE, Hult GTM. 2004. The impact of the alliance on the partners: A look at cause-brand alliances. Psychology \& Marketing 21(7): 509-531.

Lii Y, Wu K, Ding M. 2013. Doing good does good? Sustainable marketing of CSR and consumer evaluations. Corporate Social Responsibility and Environmental Management 20(1): 15-28.

Maignan I. 2001. Consumer perceptions of corporate social responsibility: A crosscultural comparison. Journal of Business Ethics 30(1): 57-72.

Maignan I, Ferrell OC, Hult GT. 1999. Corporate citizenship: Cultural antecedents and business benefits. Journal of the Academy of Marketing Science 27(4): 455-469. 
Maignan I, Ferrell OC, Farrell L. 2005. A stakeholder model for implementing social responsibility in marketing. European Journal of Marketing 39(9/10): 956-977.

Marín L, Ruiz S. 2007. "I need you too!" corporate identity attractiveness for consumers and the role of social responsibility. Journal of Business Ethics 71(3): 245260.

Matute J, Bravo R, Pina JM. 2011. The influence of corporate social responsibility and price fairness on customer behaviour: Evidence from the financial sector. Corporate Social Responsibility and Environmental Management 18(6): 317-331.

Menon S, Kahn BE. 2003. Corporate sponsorships of philanthropic activities: When do they impact perception of sponsor brand?. Journal of Consumer Psychology 13(3): 316327.

Mercer JJ. 2003. Corporate social responsibility and its importance to consumers. Doctoral Thesis, Claremont Graduate University, Claremont.

Mohr LA, Webb DJ. 2005. The effects of corporate social responsibility and price on consumer responses. The Journal of Consumer Affairs 39(1): 121-147.

Mohr LA, Webb DJ, Harris KE. 2001. Do consumers expect companies to be socially responsible? The impact of corporate social responsibility on buying behaviour. Journal of Consumer Affairs 35(1): 45-72.

Nan X, Heo K. 2007. Consumer responses to corporate social responsibility (CSR) initiatives: Examining the role of brand-cause fit in cause-related marketing. Journal of Advertising 36(2): 63-74.

Newell SJ, Goldsmith RE. 2001. The development of a scale to measure perceived corporate credibility. Journal of Business Research 52(3): 235-247.

Pérez A, Martinez P, Rodríguez del Bosque I. 2012. The development of a stakeholderbased scale for measuring corporate social responsibility in the banking industry. Service Business, published online. DOI: 10.1007/s11628-012-0171-9.

Petty R, Cacioppo J. 1986. Communication and persuasion: Central and peripheral routes to attitude change. Springer-Verlag: New York.

Podnar K, Golob U. 2007. CSR expectations: The focus of corporate marketing. Corporate Communications 12(4): 326-340.

Podsakoff PM, MacKenzie SB, Lee JY, Podsakoff NP. 2003. Common method biases in behavioural research: A critical review of the literature and recommended remedies. Journal of Applied Psychology 88: 879-903. 
Poolthong Y, Mandhachitara R. 2009. Customer expectations of CSR, perceived service quality and brand effect in Thai retail banking. International Journal of Bank Marketing 27(6): 408-427.

Pomering A, Dolnicar S. 2009. Assessing the prerequisite of successful CSR implementation: Are consumers aware of CSR initiatives? Journal of Business Ethics 85: 285-301.

Ramasamy B, Yeung MCH, Au AKM. 2010. Consumer support for Corporate Social Responsibility (CSR): The role of religion and values. Journal of Business Ethics 91: $61-72$.

Rifon NJ, Choi SM, Trimble CS, Li H. 2004. Congruence effects in sponsorship: The mediating role of sponsor credibility and consumer attributions of sponsor motive. Journal of Advertising 33(1): 29-42.

Roberts JA. 1996. Will the real socially responsible consumer please step forward?. Business Horizons 39(1): 79-83.

Sen S, Bhattacharya CB. 2001. Does doing good always lead to doing better? Consumer reactions to corporate social responsibility. Journal of Marketing Research 38(2): 225243.

Speed R, Thompson P. 2000. Determinants of sports sponsorship response. Journal of the Academy of Marketing Science 28(2): 226-238.

van Herpen E, Pennings J, Meulenberg M. 2003. Consumers' evaluations of socially responsible activities in retailing. Wageningen University Marketing and Consumer Behaviour Group.

Varadarajan PR, Menon A. 1988. Cause-related marketing: A coalignment of marketing strategy and corporate philanthropy. Journal of Marketing 52(3): 58-74.

Whitehouse L. 2006. Corporate social responsibility: Views from the frontline. Journal of Business Ethics 63(3): 279-296. 
Table 1. Relationships in a classic model to understand the formation process of customer CSR perceptions

\begin{tabular}{ll}
\hline \hline \multicolumn{1}{c}{ Causal relationship } & \multicolumn{1}{c}{ References } \\
\hline \hline Congruence $\rightarrow$ Attribution & $\begin{array}{l}\text { Rifon et al (2004); Becker-Olsen et al (2006); Ellen et al } \\
\text { (2006); Bigné et al (2009) }\end{array}$ \\
\hline Congruence $\rightarrow$ Credibility & $\begin{array}{l}\text { Rifon et al (2004); Becker-Olsen et al (2006); Bigné et al } \\
(2009)\end{array}$ \\
\hline Attribution $\rightarrow$ Credibility & Rifon et al (2004); Bigné et al (2009) \\
\hline Congruence $\rightarrow$ CSR Image & Varadarajan and Menon (1988); Hoeffler and Keller (2002) \\
\hline Attribution $\rightarrow$ CSR Image & van Herpen et al (2003) \\
\hline Credibility $\rightarrow$ CSR Image & Bigné et al (2009) \\
\hline \multicolumn{2}{c}{ Source: Compiled by author }
\end{tabular}


Table 2. Clusters profile

\begin{tabular}{l|c|c|c|c}
\hline \multicolumn{1}{c|}{ Variable } & $\begin{array}{c}\text { Cluster I } \\
\text { (Low support) } \\
9.5 \%\end{array}$ & $\begin{array}{c}\text { Cluster II } \\
\text { (Social } \\
\text { orientation) } \\
19.5 \%\end{array}$ & $\begin{array}{c}\text { Cluster III } \\
\text { (Individual } \\
\text { benefit) } \\
24.6 \%\end{array}$ & $\begin{array}{c}\text { Cluster IV } \\
\text { (High support) } \\
46.4 \%\end{array}$ \\
\hline CSR support: & $4.910^{* *}$ & $5.562 * *$ & $6.160 * *$ & $6.630^{* *}$ \\
Customers & $4.150^{* *}$ & $4.710^{* *}$ & $5.890^{* *}$ & $6.276^{* *}$ \\
Shareholders & $3.493 * *$ & $5.212^{* *}$ & $5.761 * *$ & $6.644 * *$ \\
Employees & $3.725 * *$ & $5.500^{* *}$ & $4.885 * *$ & $6.439 * *$ \\
Society & $4.471 * *$ & $5.774 * *$ & $5.967 * *$ & $6.746 * *$ \\
General & & & & \\
Gender: & $57.9 \%$ & $50.2 \%$ & $56.3 \%$ & $42.0 \%$ \\
Male & $42.1 \%$ & $49.8 \%$ & $43.7 \%$ & $58.0 \%$ \\
Female & & & & \\
Age (years): & $53.3 \%$ & $44.7 \%$ & $51.7 \%$ & $43.2 \%$ \\
Under 44 & $31.8 \%$ & $32.4 \%$ & $30.3 \%$ & $33.2 \%$ \\
45 to 64 & $14.9 \%$ & $22.9 \%$ & $18.0 \%$ & $23.6 \%$ \\
Over 64 & & & & \\
Education: & $1.9 \%$ & $6.4 \%$ & $4.0 \%$ & $3.6 \%$ \\
No education & $15.0 \%$ & $20.5 \%$ & $19.1 \%$ & $20.2 \%$ \\
Elementary & $36.4 \%$ & $38.8 \%$ & $37.5 \%$ & $42.2 \%$ \\
High School & $46.7 \%$ & $34.2 \%$ & $39.4 \%$ & $34.0 \%$ \\
College & & & & \\
Occupation: & $59.7 \%$ & $52.5 \%$ & $55.9 \%$ & $57.2 \%$ \\
Employed & $5.6 \%$ & $6.8 \%$ & $5.1 \%$ & $2.9 \%$ \\
Unemployed & $15.9 \%$ & $8.7 \%$ & $13.0 \%$ & $9.4 \%$ \\
Student & $5.6 \%$ & $8.7 \%$ & $7.2 \%$ & $9.4 \%$ \\
Housewife & $13.1 \%$ & $23.3 \%$ & $18.8 \%$ & $21.1 \%$ \\
Retired & & & & \\
\hline \hline
\end{tabular}

$* * \mathrm{p}<0.01$ 
Table 3.Measurement scales

\begin{tabular}{|c|c|}
\hline Variable & Items \\
\hline $\begin{array}{l}\text { CSR (support } \\
\text { and image) }\end{array}$ & $\begin{array}{l}\text { I believe (a) a company should... (CSR support) (b) This company... } \\
\text { (CSR image) } \\
\text { 1) Establishes procedures to comply with customers' complaints; 2) } \\
\text { Treats its customers honestly; 3) Has employees who offer complete } \\
\text { information about corporate products/services to customers; 4) Uses } \\
\text { customers' satisfaction as an indicator to improve the product/service } \\
\text { marketing; 5) Make an effort to know customers' needs; 6) Tries to } \\
\text { maximize its profits; 7) Keep a strict control over its costs; 8) Tries to } \\
\text { insure its survivals and long-term success; 9) Pays fair salaries to its } \\
\text { employees; 10) Offers safety at work to its employees; 11) Treats its } \\
\text { employees fairly (without discrimination or abuses); 12) Offers } \\
\text { training and career opportunities to its employees; 13) Offers a } \\
\text { pleasant work environment (e.g., flexible hours, conciliation); 14) } \\
\text { Helps solving social problems; 15) Uses part of its budget for } \\
\text { donations and social projects to advance the situation of the most } \\
\text { unprivileged groups of the society; 16) Contributes money to cultural } \\
\text { and social events (e.g., music, sports); 17) Plays a role in the society } \\
\text { beyond the economic benefits generation; 18) Is concerned with } \\
\text { improving the general well-being of society; 19) Is concerned with } \\
\text { respecting and protecting the natural environment; 20) Always } \\
\text { respects rules and regulations defined by law; 21) Is concerned with } \\
\text { fulfilling its obligations vis-à-vis its shareholders, suppliers, } \\
\text { distributors and other agents with whom it deals; 22) Is committed to } \\
\text { well established ethic principles }\end{array}$ \\
\hline $\begin{array}{l}\text { Company-CSR } \\
\text { congruence }\end{array}$ & $\begin{array}{l}\text { 1) Carrying out CSR activities is compatible with this institution's } \\
\text { core business; 2) It makes sense that this institution carries out CSR } \\
\text { activities; 3) Carrying out CSR activities is complementary to this } \\
\text { institution's core business; 4) There is a logical fit between the core } \\
\text { business of this institution and the CSR activities that it carries out }\end{array}$ \\
\hline $\begin{array}{l}\text { Motivational } \\
\text { attribution }\end{array}$ & $\begin{array}{l}\text { This company... } \\
\text { 1) Acts unselfishly; 2) Is altruistic; 3) Acts guided by the global } \\
\text { benefit of its stakeholders instead of by its self-interest; 4) Is } \\
\text { generous }\end{array}$ \\
\hline $\begin{array}{l}\text { Corporate } \\
\text { credibility }\end{array}$ & $\begin{array}{l}\text { This company... } \\
\text { 1) Has a great expertise in corporate social responsibility; 2) Is } \\
\text { competent in the implementation of its responsibilities towards its } \\
\text { stakeholders; } 3 \text { ) Its commitment to its stakeholders is credible; 4) Is } \\
\text { honest about its commitment to its stakeholders }\end{array}$ \\
\hline
\end{tabular}


Table 4.Structural equation modelling: H1 to H6

\begin{tabular}{ccccc}
\hline \hline Hypothesis & Causal relationship & Std. coefficient & T-value & Contrast \\
\hline \hline H1 & Congruence $\rightarrow$ Attribution & 0.266 & $7.072^{*}$ & Accepted \\
H2 & Congruence $\rightarrow$ Credibility & 0.437 & $10.907^{*}$ & Accepted \\
H3 & Attribution $\rightarrow$ Credibility & 0.459 & $12.848^{*}$ & Accepted \\
H4 & Credibility $\rightarrow$ CSR image & 0.290 & $5.101^{*}$ & Accepted \\
H5 & Congruence $\square$ CSR image & 0.235 & $5.665^{*}$ & Accepted \\
H6 & Attribution $\square$ CSR image & 0.213 & $4.476^{*}$ & Accepted \\
\hline \hline p $<0.05 ;$ Goodness of fit indexes: S-B $\chi^{2}=33.40(\mathrm{p}=0.00) ; \mathrm{NFI}=0.915 ;$ NNFI $=0.927 ;$ \\
CFI $=0.930 ;$ IFI $=0.931$
\end{tabular}


Table 5. Multisampling analysis: H7a to H7f

\begin{tabular}{|c|c|c|c|c|c|c|c|c|c|c|c|c|}
\hline \multirow[b]{2}{*}{ Hypothesis } & \multirow[b]{2}{*}{$\begin{array}{c}\text { Causal } \\
\text { relationship }\end{array}$} & \multicolumn{4}{|c|}{ Standardised loadings (t-value) $^{l}$} & \multicolumn{6}{|c|}{ Dif. $\chi^{2}(1)$} & \multirow[b]{2}{*}{ Contrast } \\
\hline & & Low (I) & Social (II) & $\begin{array}{c}\text { Individual } \\
\text { (III) }\end{array}$ & High (IV) & I-II & I-III & I-IV & $\begin{array}{l}\text { II- } \\
\text { III }\end{array}$ & II-IV & $\begin{array}{l}\text { III- } \\
\text { IV } \\
\end{array}$ & \\
\hline $\mathrm{H} 7 \mathrm{a}$ & $\begin{array}{l}\text { Congruence } \rightarrow \\
\text { Attribution }\end{array}$ & 0.14 & $0.26(3.00 *)$ & $0.30(4.05 *)$ & $0.21(3.97 *)$ & - & - & - & 0.01 & 0.04 & 0.28 & $\begin{array}{l}\text { Accepted } \\
(\mathrm{p})^{2}\end{array}$ \\
\hline $\mathrm{H} 7 \mathrm{~b}$ & $\begin{array}{l}\text { Congruence } \rightarrow \\
\text { Credibility }\end{array}$ & $0.48(4.31 *)$ & $0.38(3.50 *)$ & $0.29(3.47 *)$ & $0.38(5.80 *)$ & $4.51 *$ & $5.01 *$ & $4.87 *$ & 0.15 & $3.96^{*}$ & 1.59 & Rejected \\
\hline $\mathrm{H} 7 \mathrm{c}$ & $\begin{array}{l}\text { Attribution } \rightarrow \\
\text { Credibility }\end{array}$ & 0.20 & $0.44(4.68 *)$ & $0.55(5.38 *)$ & $0.53(9.72 *)$ & - & - & - & 0.20 & 0.00 & 0.01 & $\begin{array}{l}\text { Accepted } \\
(\mathrm{p})\end{array}$ \\
\hline $\mathrm{H} 7 \mathrm{e}$ & $\begin{array}{l}\text { Congruence } \\
\rightarrow \text { CSRImg }\end{array}$ & 0.14 & 0.01 & 0.10 & $0.20(2.93 *)$ & - & - & - & - & - & - & Accepted \\
\hline $\mathrm{H} 7 \mathrm{f}$ & $\begin{array}{l}\text { Attribution } \\
\rightarrow \text { CSRImg }\end{array}$ & 0.13 & 0.04 & $0.23(2.44 *)$ & $0.32(4.71 *)$ & - & - & - & - & - & $0.13^{*}$ & Accepted \\
\hline
\end{tabular}

*p-value $<0.05$; Goodness of fit indexes: S-B $\chi 2$ (502)=945.60 (p=0.00); NFI=0.880; NNFI=0.934; CFI=0.939; IFI=0.939

Goodness of fit indexes --> Low involvement: S-B $\chi 2(112)=147.83(\mathrm{p}=0.01) ; \mathrm{NFI}=0.715 ; \mathrm{NNFI}=0.886 ; \mathrm{CFI}=0.906 ; \mathrm{IFI}=0.912$

Medium involvement: S-B $\chi 2(112)=200.34(\mathrm{p}=0.00) ; \mathrm{NFI}=0.841 ; \mathrm{NNFI}=0.904 ; \mathrm{CFI}=0.921 ; \mathrm{IFI}=0.923$

Individual benefit: $S-B \chi 2(112)=169.04(\mathrm{p}=0.00) ; \mathrm{NFI}=0.896 ; \mathrm{NNFI}=0.953 ; \mathrm{CFI}=0.962 ; \mathrm{IFI}=0.962$

High involvement: $\mathrm{S}-\mathrm{B} \chi 2(112)=280.03(\mathrm{p}=0.00) ; \mathrm{NFI}=0.922 ; \mathrm{NNFI}=0.941 ; \mathrm{CFI}=0.952 ; \mathrm{IFI}=0.952$

\footnotetext{
${ }^{1}$ In italics, non-significant relationships ( $\left.p<0.05\right)$.
}

2 (p) $=$ partially 
Figure 1.Conceptual model

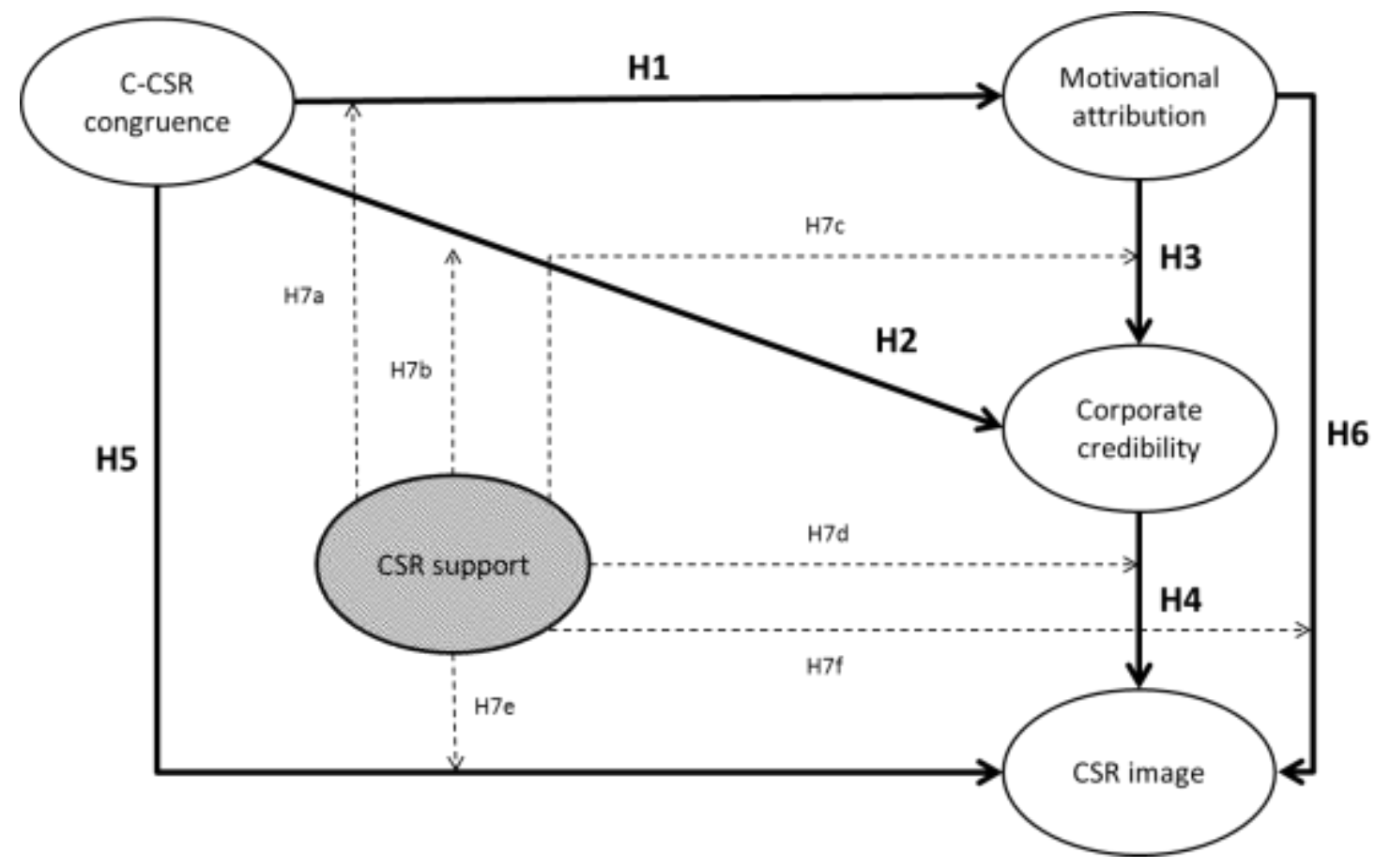

